\title{
Foreign Portfolio Investment and Earnings Quality: Evidence from Sri Lanka
}

Wijesinghe M. R. P. ${ }^{1}$ and De Silva A.L.C.M. ${ }^{2}$

${ }^{1}$ Department of Finance, University of Kelaniya, Sri Lanka

${ }^{2}$ Department of Finance, University of Kelaniya, Sri Lanka

${ }^{1}$ ruwanmrp@kln.ac.lk, ${ }^{2}$ chathurinidesilva@gmail.com

\begin{abstract}
The development flows signs renewed foreign interest in the stock market during mid-2017, recording an all-time high in foreign purchases. With the realization of investment opportunities and potential in capital markets in Sri Lanka, foreign investors actively participated in trading in CSE making volatility in Foreign Portfolio Investment (FPI), which lead the researcher to investigate the determinants of FPI under company performance (ROA, ROE and OPM), market-specific factors (MC, MI and BETA), earnings quality (EQ) measured by total accruals (TA) and macro-economic variables (IR and GDP) using evidence from Sri Lanka. Using the three dependent variables of TNFP, TFP, and TFS the researcher analyzed quarterly data for the period from 2011 to 2016 under panel data regression model and concluded, ROE, MC, MI, BETA, GDP Growth and IR has a significant relationship with foreign portfolio investment where the results suggested earnings quality does not have any impact on foreign portfolio investment. The findings of the study are especially useful for potential investors, regulators and the interested parties of investment decisions.
\end{abstract}

Keywords: Colombo Stock Exchange, Earnings Quality, Foreign Portfolio Investment, Macro-Economic variables

Copyright: () 2021 Wijesinghe M.R.P. and De Silva A.L.C.M. This is an open access article distributed under the Creative Commons Attribution License, which permits unrestricted use, distribution, and reproduction in any medium, provided the original work is properly cited.

Correspondence: ruwanmrp@kln.ac.lk

ORCID of authors: $\quad$ Wijesinghe M. R. P.: https://orcid.org/0000-0002-2862-6641

DOI: http://doi.org/10.4038/kjm.v10i0.7680 


\section{Introduction}

Sri Lanka is a country that has overcome a dark era of terrorism, and it is a country that has had rapid growth afterward. This postwar period became the golden era of Sri Lanka, where the economy and infrastructure have developed rapidly and people's standard of living has improved at the same time coupled with political stability. During this period, the foreign investors have paid serious attention to investment opportunities in Sri Lanka and this has caused an inflow of foreign investment into the country in the modes of Foreign Direct Investment (FDI), Foreign Portfolio Investment (FPI) and Other Investment (Liyanage, 2016). This FPI mainly refers to the foreign purchasing and selling of shares and this paper concentrates on the determinants of foreign purchasing and sale of shares.

Foreign Purchases, which were first allowed in 1990, increased rapidly to almost USD 300 million in 1994. However, after 1994, stock market activity by foreigners subsided, and net foreign purchases have remained at negative or near-zero levels thereafter. Foreign ownership peaked at $20 \%$ of the market in 1997 , bottomed at $11 \%$ in 2000 . This can be explained through the economic liberalization which happened during 1977 where the Sri Lankan government took steps to open the economy to the outside world. Although there was a policy on FDI before 1977, less FDI was coming into the country with the unfavorable economic condition during that period. Looking at the recent history, during 2012 foreign inflows achieved an all-time record of 38.6 billion, whereas in 2013 the net foreign inflow amounted to 22.7 billion Rupees. Repeatedly as in 1994 to 1997 , in 2015 it recorded a net outflow of 5.3 billion Rupees. As the most recent incident on 9th June 2017, the net foreign inflow reported top Rs. 20 billion marks, shifting towards three years high.
By looking at the above statistics, it is evident that the stock market activity has been highly volatile and has been driven by market sentiments as well as by the stability of the country. In view of the determinants of FPI, preceding studies have identified different factors such as; the growth rate of real GDP, real interest rate, real exchange rate, gross capital flow, market capitalization, institutional quality and trade degree of openness (Ekeocha et al., 2008; Ekeocha et al., 2012; Hansen et al., 2015). However, they have not considered the company-specific factors such as Return on Assets (ROA), Return on Equity (ROE), which means that less concentration has been paid to identify company performance and earnings quality as determinants of FPI.

Moreover, it is evident that the studies to examine the determinants of the FPI has not been considered earnings quality as a determinant of the FPI. This is mainly because earnings quality is an important determinant to allocate the investors' resources (Amr et al., 2019). The importance of earnings for the investors is highlighted in the International Accounting Standard Board (IASB, 2018), and as Schipper and Vincent (2003) explain, the low quality of earnings will provide defective resource allocation signals investors. When considering the Sri Lankan context, there is a number of studies available to investigate foreign direct investments (Thilakaweera, 2012; Mustafa and Santhirasegaram, 2014; Balamurali \& Bogahawatte, 2004) whereas limited studies examined the on FPI. For example, Ariyarathna and Wijesinghe (2014) and Kumara and Dayaratne (2015) examined FPI.

Nevertheless, no studies combine the company-specific, market-specific, earnings quality, and macro-economic factors to investigate the FPI. Therefore, the current study addresses the existing gap, particularly in Sri Lanka, to investigate the determinants of FPI coupled with company-specific factors, market-specific factors, earnings quality factors and macro-economic factors. 
Hence, our study becomes original to examine the impact of earnings quality on FPI. With this, we derive two main objectives. Firstly, we investigate whether company performance affects the investment decision of foreign investors. Secondly, examine whether market-specific factors, earnings quality, and macroeconomic factors affect foreign investors' investment decisions.

The remaining part of this paper is arranged as follows. The following section discusses the related previous studies, and section three focuses on the methodology concerns. Then the results and the discussion are presented, followed by the study's conclusion, including the limitations and the directions for future studies.

\section{Literature Review}

The capital inflows to an economy have different sources, and Foreign Direct Investment (FDI) and the Foreign Portfolio Investment (FPI) are the two main categories of investments (Ariayarathne and Wijesinghe, 2014; CBSL, 2020). An inflow is identified as FDI if the investor holds at least $10 \%$ of the domestic enterprise and FPI is identified as holding the stake of a domestic company less than $10 \%$. This FPI includes the purchase and sale of shares and other securities (Liyanage, 2016).

There are many theories developed to explain the determinants of capital flows. According to the Standard Neoclassical Theory, capital flows are driven by return differentials among countries. If there are no restrictions, capital will flow where returns are higher, and capital is relatively scarce, i.e. to developed countries. The second key theory is based on the Capital Asset Pricing Model (CAPM). When securities from different countries show low levels of correlations, investing in foreign assets improves the efficiency of a portfolio by reducing its overall variance (Bonizzi, 2013). Another theoretical aspect is that the Efficient Market Hypothesis (EMH) developed by Fama (1970) states that; an efficient Capital Market is one which security prices adjust rapidly to the arrival of new information and, therefore, the current prices of securities reflect all information about the security. This is referred to as an informationally efficient market. This hypothesis implies that no investment strategy based on current or historical information gains extraordinary large profits. According to EMH the investors act quickly to new information. It means that whenever new information arrives to the market, the investors start buying, selling, or holding shares in respect of a capital market. This applies for investing in both home country and in a foreign country. Based on that, we can expect that the foreign investors who invest in Sri Lankan listed companies will also act according to the theory proposed by Fama (1970), assuming the current share prices reflect all information.

After looking at the study's theoretical aspect, we assessed previous studies to identify the relevance of the current study. In the course of determining the long run determinants of FPI, Ekeocha (2008) and Ekeocha et al., (2012) identified Market Capitalization, Sovereign Risk Premium, Real Exchange Rate, Level of Institutional Quality, Investment, Real Interest Rate, Level of Financial Openness and Trade Openness as the long-run determinants of FPI. Ekeocha (2008) found that Real GDP, real interest rate, gross capital flow ratio, and institutional quality are positively related to FPI. There is a negative relationship between the predictors of real exchange rate, market capitalization, trade degree openness and the dependent variable, FPI. However, Ekeocha et al., (2012) revealed that foreign portfolio investment has a positive long-run relationship with market capitalization and trade openness.

Agarwal (1997) found that concerning developing countries, inflation rate, real exchange rate, index of economic activity, share of domestic capital market in the world stock market capitalization, foreign direct 
investment, total foreign trade, and current account deficit as determinants of FPI. Based on the results, Agarwal (1997) revealed that inflation rate, real exchange rate, economic activity index, and domestic capital market share in the world stock market capitalization are statistically significant as determinants of FPI. Furthermore, the researcher also identified that inflation and FPI have a negative relationship where real exchange rate, index of economic activity, the share of domestic capital market in the world stock market capitalization have a positive relationship with the dependent variable, FPI. Nevertheless, Gumus et al., (2013) establish that change in foreign portfolio investment affects Istanbul Stock Exchange Price Index and Exchange Rates. In addition, the researcher has also found that only the industrial production index affects foreign portfolio investment in the short run.

In the case of South Asian countries (China, India, Pakistan and Sri Lanka) Waqas et al., (2015) used GDP Growth rate, CPI as a proxy for the inflation rate, annual real exchange rate, interest rate differential, FDI, stock market returns and to measure industrial production growth, industrial production index as the variables to the study. The results suggested that there is a significant relationship between macroeconomic variables and foreign portfolio investment volatility. Volatility in foreign portfolio investment is associated with a high interest rate, currency depreciation, foreign direct investment. Lower inflation and higher GDP growth rate of the host country. The findings further suggested that the foreign portfolio investors are looking at the stable macroeconomic environment of the country they are planning to invest in.

With the studies, we can identify that numerous scholars employed many macroeconomic variables to quantify what determines the FPI in the international context. In Sri Lankan context, Liyanage (2016) investigated the causes of capital flows into Sri Lanka in the push and pull factors, using the Fully Modified Ordinary Least Square approach and the Vector Error Correction Model. The study found that capital flows are attracted primarily to pull factors such as real GDP, interest rates, and political stability. The study also establishes that the fundamental causes of capital flow in disaggregate levels differ. These results suggest that Sri Lanka needs to pay close attention to keeping domestic macroeconomic variables in the correct sequence to attract foreign capital.

The next important question is, is it only the macroeconomic factors that determine the FPI? How about company-specific aspects? In this milieu, Hariprasad (2016) investigated several firm-level characteristics in the Indian context and makes public that the firm size and the bookto-market ratio are significant variables in selecting the equity investments by investors. Further, Aydin et al., (2007) reveal that the firms with foreign ownership operating in Turkey perform better than the domestic owned ones regarding ROAs. The evidence supports the hypothesis that foreign ownership participation increases the performance of firms. Moreover, while studies (MoIlah and Talukdar, 2007; Douma et al., 2002; Hansen et al., 2015) identify a positive impact from FPI to the company performance, some studies (for example, Barbosa and Louri, 2003; Khawar, 2003) identifies that there is no impact or the negative impact to the company performance.

In the same vein, it is essential to note that it is rare that previous studies have employed both macro-economic variables and the company-specific factors to investigate whether both factors determine the FPI. For example, Hansen et al., (2015) concentrated only on firm-specific factors such as US Listing, Market Capitalization, Market Index, ROA, Big $\mathrm{N}$ Auditor, Leverage, Dividend Yield, Controlling Shareholder, Market to Book Value, Foreign Sales and Domestic Institutional Ownership to test the 
firm-level transparency. The study found that the firm-level transparency is positively related to foreign ownership.

Having looked at the relationship between the FPI and the company performance, it is paramount to see the studies investigating PFI and earnings quality. As per the literature survey conducted, we can not identify direct research examining FPI and earnings quality, especially in the Sri Lankan context. The majority of the earnings quality studies explore either determinant of earnings quality or the consequence of earnings quality (Dechow, 2010). Especially in the Sri Lankan context, few studies are available on the earnings quality (Rajeevan \& Ajward, 2019; Wijesinghe \& Kehelwalatenna, 2017; Wijesinghe \& Kavinda, 2017) and the aspect of FPI has not been addressed as per the review of prior studies.

When considering the studies on FPI in Sri Lanka, Kumara and Dayaratne (2015) examined the determinants of FPI in Sri Lanka. They employed London Inter-Bank Offered Rates (LIBOR), foreign reserves presented in months of imports, USD/LKR exchange rate, and All Share Price Index (ASPI) as independent variables and concluded that ASPI has a statistically significant and long-run positive effect on foreign purchases. Ariyarathna and Wijesinghe (2014) concluded that net foreign investments have a causal impact on the Colombo stock exchange performance. However, it seems that the macroeconomic factors, company-specific factors, and earnings quality have not been combined to examine the foreign portfolio investments.

\section{Methodology}

The population considered for the study comprised all the listed companies at CSE. We considered 212 sample companies (Please refer to Appendix A) that have foreign stakes during the period from 2011 to 2016. The data for this study is collected through CSE data library, CBSL data library, and quarterly interim reports of companies published on the CSE website.

We developed three models to be carried out using panel data regression analysis employing E-views. Based on three dependent variables, namely TNFP, TFP and TFS we develop the following three models.

\section{Model 1}

$$
\begin{aligned}
& \mathrm{TNFP}=\beta 0+\beta 1 \mathrm{RoA}+\beta 2 \mathrm{RoE}+\beta 3 \mathrm{OPM}+ \\
& \beta 4 \mathrm{MC}-\beta 5 \mathrm{BETA}+\beta 6 \mathrm{MI}-\beta 7 \mathrm{TA}+\beta 8 \mathrm{GDP} \\
&+\beta 9 \mathrm{IR}+\mathrm{Ui}
\end{aligned}
$$

\section{Model 2}

$$
\begin{gathered}
\mathrm{TFP}=\beta 0+\beta 1 \mathrm{RoA}+\beta 2 \mathrm{RoE}+\beta 3 \mathrm{OPM}+ \\
\beta 4 \mathrm{MC}-\beta 5 \mathrm{BETA}+\beta 6 \mathrm{MI}-\beta 7 \mathrm{TA}+\beta 8 \mathrm{GDP} \\
+\beta 9 \mathrm{IR}+\mathrm{Ui}
\end{gathered}
$$

\section{Model 3}

$$
\begin{aligned}
\text { TFS } & =ß 0-\beta 1 \text { RoA }-\beta 2 \text { RoE }-\beta 3 O P M- \\
\beta 4 \mathrm{MC} & +\beta 5 \text { BETA }-\beta 6 \mathrm{MI}+\beta 7 \mathrm{TA}-\beta 8 \mathrm{GDP} \\
& -\beta 9 \mathrm{IR}+\mathrm{Ui}
\end{aligned}
$$

Where, TNFP equals to Total Net Foreign Purchases, B0 equals to the Intercept coefficient, ROA equals to Return on Assets, ROE equals to Return on Equity, OPM equals to Operating Profit Margin, MC equals to Market Capitalization, BETA equals to Company Beta, MI equals to Market Index, TA equals to Total Accruals, GDP equals to GDP Growth, IR equals to Real Interest Rate and Ui equals to the Error Term.

ROA is defined as a profitability ratio that measures the net income produced by total assets during a period by comparing net income to the average total assets. In other words, ROA measures how efficiently a company can manage its assets to produce profits during the period. We calculate ROA as follows. 
ROA $=$ Net Income/Average Total Assets (4)

OPM is operating profit before interest and taxes to the book of sales. This ratio demonstrates how much revenue left after all variable operating costs such as raw material costs have been paid. This ratio shows how strong and profitable a company's operations are. Equation 5 represents the OPM calculation.

$\mathrm{OPM}=$ Earnings before Interest and Tax

(EBIT)/ Revenue

ROE is defined as profit after tax (Net Income) to the book value of total equity. This ratio tests the ability of a company to generate profits by using the shareholders' investment and has been calculated as presented in equation 6 .

\section{ROE $=$ Net Income / Total Shareholders' Equity

The researcher has used the following formula to arrive at the total shareholder's Equity (Equation 7).

Total Shareholders' Equity $=($ Total Assets

$$
\text { - Total Liabilities) }
$$

The accruals Model is one of the commonly used methods of measuring earnings quality. As discussed in the literature review, this study mainly identifies the accruals quality aspect of earnings quality. There are two approaches discussed in the prior studies. Balance Sheet Approach (Healy,1985; Jones, 1991) and Cash Flow Statement Based Approach (Dechow et al.,1995). However, Hribar and Collins (2002) identify that the cash flow based approach is the better approach that we employed in this study to calculate total absolute accruals. Equation 8 shows the formula for calculating Total Accruals (TA).

$$
\mathrm{TA}=\mathrm{NI}-\mathrm{CFO}
$$

Where;
$\mathrm{NI}=$ Net Income

$\mathrm{CFO}=$ Cash Flows from Operations

\section{Hypotheses of the study}

The hypotheses for this study are being developed based on the EMH theory (Fama, 1970) where it assumes that the markets are informationally efficient and prices are adjusted based on new information. In simple terms, EMH suggests that the stock prices will reflect and change according to the new information type. Favorable information leads to rising stock prices due to high demand. When there is negative information, the stock prices fall due to excess selling about the companies which is also in line with the informational theory.

The following hypotheses can be outlined based on the above theoretical backdrop and the other theories and the previous studies discussed in the literature review.

\subsubsection{Hypotheses for Model 1 and 2}

$\mathrm{H} 1_{1}$ - There is a Positive and Significant relationship between ROE and TNFP/TFP.

$\mathrm{H} 2{ }_{1}$ - There is a Positive and Significant relationship between ROA and TNFP/TFP.

$\mathrm{H} 3_{1}$ - There is a Positive and Significant relationship between OPM and TNFP/TFP.

$\mathrm{H} 4_{1}$ - There is a Positive and Significant relationship between MC and TNFP/TFP.

H5 - There is a Negative and Significant relationship between BETA and TNFP/TFP.

H6 - There is a Positive and Significant relationship between MI and TNFP/TFP.

H7 ${ }_{1}$ - There is a Negative and Significant relationship between TA and TNFP/TFP.

H8 ${ }_{1}$ - There is a Positive and Significant relationship between GDP and TNFP/TFP. 
Wijesinghe M.R.P., De Silva, A.L.C.M., KJM, 2021, 10 (Special Issue)

$\mathrm{H} 9_{1}$ - There is a Positive and Significant relationship between RI and TNFP/TFP.

\subsubsection{Hypotheses for Model 3}

$\mathrm{H} 1_{1}$ - There is a Negative and Significant relationship between ROE and TFS.

$\mathrm{H} 2_{1}$ - There is a Negative and Significant relationship between ROA and TFS.

$\mathrm{H} 33_{1}$ - There is a Negative and Significant relationship between OPM and TFS.

$\mathrm{H} 4_{1}$ - There is a Negative and Significant relationship between MC and TFS.

H51 - There is a Positive and Significant relationship between BETA and TFS.

H6 ${ }_{1}$ - There is a Negative and Significant relationship between MI and TFS.

H7 1 - There is a Positive and Significant relationship between TA and TFS.

$\mathrm{H} 8_{1}$ - There is a Negative and Significant relationship between GDP and TFS.

$\mathrm{H} 9_{1}$ - There is a Negative and Significant relationship between RI and TFS.

\section{Findings and Discussion}

We can identify that the mean value of the foreign sales is higher than the purchases in the sample period. A summary of descriptive statistics is given under Appendix B - Table 16 for further details.

Panel Unit Root Test has been considered to test the stationarity of the series. Based on the results outlined in "Appendix C", only LIR is not a stationary series at a level, so this series was converted into its first difference make it a stationary series. The results are shown in "Appendix C".

Table 1: Heteroscedasticity White Test

\begin{tabular}{lccc}
\hline Statistic & TNFP & TFS & TFP \\
\hline $\begin{array}{l}\text { Obs*R- } \\
\text { squared }\end{array}$ & 481.1578 & 431.3388 & 682.0201 \\
$\begin{array}{l}\text { Prob. Chi- } \\
\text { Square (54) }\end{array}$ & $0.0000^{* *}$ & $0.0000^{* *}$ & $0.0000^{* *}$ \\
\hline
\end{tabular}

Note: Number of observations 5088. ** indicate that the probabilities are significant at $1 \%$ level.

Based on the white test (presented in Table 1 above) all three models had heteroscedasticity problem. To remove the

heteroscedasticity from the models all variables have been converted to their log form. Using the stationary independent variables, a correlation matrix has been obtained, and based on the results presented in "Appendix D", LROA and LROE had the highest correlation out of the nine explanatory variables correlating $78.31 \%$, which is closer to the $80 \%$ threshold (Using Econometrics a Practical Guide, 2014). LROA, which had the highest probability of the two highly correlated variables, was removed from model estimation to remove the multicollinearity.

Before estimating the models using E-views the researcher carried out the Hausman Test to recognize whether a fixed effect or a random effect is appropriate for the three models.

Table 2: Hausman Test

Statistic Model $1 \quad$ Model 2 Model 3

Chi-Sq. $\quad 14.2323 \quad 31.4963 \quad 26.2482$

Statistic 
Wijesinghe M.R.P., De Silva, A.L.C.M., KJM, 2021, 10 (Special Issue)

Prob. $\quad 0.07590 .0001 * * \quad 0.0010 * *$

Note: ** represent probabilities significant at $1 \%$ level.

Based on the results presented in Table 2 above, model one is not significant. Hence, a random effect is appropriate while models two and three was significant at $1 \%$ level i.e., the test suggested that fixed affect model is suitable for model two and three.

For Model two and three, which were identified as fixed effect is appropriate, a Redundant Fixed Effect Likelihood Ratio Test has been carried out to recognize whether a pooled regression is appropriate, or a fixed affect model is appropriate. Based on the test results (Table 3), it is suggested that the fixed effect is appropriate for both models.

\section{Table 3: Redundant Fixed Effect Likelihood Ratio Test}

\begin{tabular}{lcc}
\hline Statistic & Model 2 & Model 3 \\
\hline $\begin{array}{l}\text { Cross- } \\
\text { section F }\end{array}$ & 4.2160 & 4.8551 \\
Prob. & $0.0000 * *$ & $0.0000^{* *}$
\end{tabular}

Note: Number of observations Model 2 1415, Model $3-1483$, ** represents the probabilities are significant at $1 \%$ level.

Considering the test results of both the Hausman Test and the Redundant Fixed Effect Likelihood Test, for the first model, a random effect regression was carried out while a fixed affect approach was exercised for the model two and three and the summary of the results are outlined as below.

\section{Random Effect Test Results for Model One}

According to the test results presented in Appendix E Table 19, the R squared was $23.20 \%$, indicating that the explanatory power of the independent variables was $23.20 \%$, i.e. the explanatory variables can predict a $23.20 \%$ change in the dependent variable TNFP. The adjusted $\mathrm{R}$ squared was $22.50 \%$. The overall model was significant at $1 \%$ level represented a 0.0000 probability value of the F- a statistic which expressed that the overall model was acceptable.

The value of the intercept coefficient was 26.32 , which indicated that the value of total net foreign purchases was -26.32 when all the explanatory variables were at zero level. The coefficient of LROE represented a positive value of $0.2151(21.51 \%)$ indicated a positive relationship with LTNFP. The tvalue was 2.6408 and the corresponding probability value was 0.0084 , which indicated that LROE was a significant variable as well.

The LMC and LMI also had a positive relationship with LTNFP having coefficients of 1.0624 and 2.0529 respectively. The corresponding t-values and the probabilities explained that these two variables were significant in determining total net foreign purchases.

In contrast, LOPM, LBETA, and DLIR had negative coefficients of $-0.1548,-0.2143$, and -0.8686 , respectively, which indicated an inverse relationship with the dependent variable LTNFP. Among these variables, LBETA and DLIR were significant at $1 \%$ level and 5\% level, which showed a negative and significant relationship with the dependent variable.

\section{Fixed Effect Test Results for Model Two}

As presented in "Appendix E", Table 20, Model two had an $\mathrm{R}$ squared value of $63.90 \%$ which indicated a $63.90 \%$ explanatory power of independent variables and an adjusted $\mathrm{R}$ squared was $57.87 \%$. The F- Statistic value was significant at $1 \%$ level 
which indicated the overall model was significant.

The value of the intercept coefficient was 37.81 which indicated that, when all the independent variables were at zero level the total foreign purchases were -37.81. LROE, LOPM, LMC, LMI and LGDP which had positive coefficients of $0.1596(15.96 \%)$, 0.0794 (7.94\%), 1.7168, 1.9108 and 0.1914 $(19.14 \%)$ respectively indicated that there was a positive relationship with total foreign purchases out of which LROE, LMC, LMI and LGDP were significant which had $\mathrm{t}-$ values of 2.0292, 8.7070, 3.1028 and 2.4070 with probabilities of $0.0426,0.0000,0.0020$ and 0.0162 .

LTA, LBETA and DLIR had a negative relationship with the dependent variable which had coefficient values -0.0438 , 0.0973 and $-0.7680(76.8 \%)$ and only the DLIR was significant at $1 \%$ level indicated a probability value of 0.0000 .

\section{Fixed Effect Teat Results for Model Three}

Based on the results outlined in "Appendix E", Table 21, the dependent variable for model three was total foreign purchases. It had a $63.68 \% \mathrm{R}$ squared and a $57.38 \%$ adjusted $\mathrm{R}$ squared, representing a $63.68 \%$ explanatory power of the independent variables. The overall model was significant at $1 \%$ level with a 0.0000 probability value for the F- statistic.

The value of the intercept coefficient was 52.87 which explained that when all independent variables were at zero level the value of total foreign sales was -52.87 . In this model LROE, LOPM, LMC, LMI, LGDP and LBETA exhibited a positive relationship with the dependent variable had coefficient values of $0.0969,0.0524,1.8528$, $3.2050,0.1724$ and 0.2066 respectively. Among them LMC, LMI, LGDP and LBETA were significant at $1 \%$ level indicated a positive and significant relationship with the dependent variable.
LTA and DLIR had negative coefficients i.e. when the total foreign sales increase, LTA and DLIR reduces. Both of these variables were not significant which indicated 0.4547 and 0.1158 probabilities.

According to the above test results, in respect of ROE, MC and MI the alternative hypotheses were accepted in model one and two indicating a positive and significant relationship with TNFP/TFP. In respect of BETA, both models one and three accept the alternative hypotheses showing a significant but negative relationship (Model 1) and a positive but significant relationship (Model $3)$. However, in model two, the results suggested a insignificant but negative relationship, leading the researcher to accept the null while rejecting the alternative hypothesis. Looking at the results obtained for GDP, in model one, the alternative hypothesis was rejected, showing no significant relationship with TNFP however, in model two, the alternative hypothesis was accepted, establishing a significant positive relationship with TFP. Although GDP was significant in determining TFS in model three, the results suggested a positive and significant relationship that was the opposite of the researcher's expectation on hypothesis. No model suggested that OPM significantly influenced either TNFP, TFP or TFS, leading the researcher to reject alternative hypotheses developed.

Similarly, no model recommended that TA the earnings quality measure was significant in determining FPI. In respect of IR model one and two suggested a significant relationship with TNFP and TFP; however, the relationship was negative. In model three, IR had a negative relationship with TFS; however, the relationship was insignificant, resulting in rejection of the alternative hypothesis of IR.

\section{Conclusion}

This study examined whether the Company Performance, Earnings Quality, and MacroEconomic Factors affect the Foreign 
Portfolio Investment in the Sri Lankan context. We used 212 listed companies in the Colombo Stock Exchange from 2011 - 2016 and analyzed the quarterly data using $\mathrm{E}$ Views. ROE, ROA, OPM, MC, BETA, MI, TA, GDP Growth, and Real Interest Rate are considered as the independent Variables while dependent variables of the study are Total Net Foreign Purchases (TNFP), Total Foreign Sales (TFS) and Total Foreign Purchases (TFP).

Based on the results of all three models ROE, MC, MI, GDP, IR, and BETA determine the foreign portfolio investment significantly. These results suggest that these factors affect the decision of the foreign investors, both individuals and institutions, to invest in the Colombo Stock Exchange. The independent variables have been segregated into company-specific factors, earnings quality factors, and macroeconomic factors. These significant variables represent a company-specific factor, all three market-specific factors, and all macro-economic factors considered as they impact on determining the foreign portfolio investment. No model suggested that TA (Earnings Quality Measure) is significant or significantly affects foreign portfolio investment regarding TNFP, TFP or TFS. Hence, in simple terms, except for the earnings quality, all three categories have been identified as having a significant impact on foreign portfolio investment.

Considering the study's objectives, we can conclude that the company performance affects the decision of foreign investors in investing in Sri Lankan Stock Exchange listed companies in respect of ROE. Marketspecific factors of MC, BETA, and MI affect foreign investors' decision to invest in Sri Lankan Stock Exchange. Additionally, we can see that macro-economic factors of GDP and IR affect foreign investors' decision in investing in Sri Lanka. However, Earnings quality measured through TA does not affect foreign investors' decision to invest in Sri Lanka.
Based on the results obtained, we can identify that the most significant variable in the company performance category was ROE, calculated as net income divided by total shareholders' equity. The results suggested that all the companies should try to increase the rate of return for the shareholders, in other words, ROE, by making the companies profitable in a sustainable manner so that the foreign investors willingly invest in the future ventures of the companies taking the risk of being a shareholder.

All the three variables considered under market-specific factors (MC, BETA, and MI) are significant in all three models. Market capitalization is a measure of the size of the business. The companies should try to increase $\mathrm{MC}$ by attracting more investors offering bonus shares, having the right issues, and paying dividends without going for new share issues, which can lead to losing the controlling power of the company. Furthermore, this will encourage the existing shareholders to increase their investments.

BETA being the measure of risk of a company compared to the market, the companies should always try to reduce the company BETA by beating the competition. And trying to increase the market share not only in respect of profitability but also concentrating on both the employees and the environment as well i.e. the company should go for a sustainable growth internally and externally.

The All Share Price Index moves with the changes in the share prices of all listed companies in the stock exchange. Thus, all the companies work together towards achieving sustainable growth while providing better returns for the shareholders, then the share prices of all companies will improve so that the market ASPI value will increase, which will impact the decision of foreign investors investing in the Sri Lankan listed companies. In the macro-economic variable category, GDP growth has been identified as a significant variable in 
determining foreign portfolio investment. This suggests that the economic growth should be at a stable level for the foreign investors to come and invest in the companies since economic growth directly affects the performance of the companies as well. The Sri Lankan government and the Central Bank of Sri Lanka have the prime responsibility of establishing proper policies, rules, and regulations and helping companies increase their businesses to keep the GDP growth stable.

Another macro-economic factor that has been identified as significant is the Real Interest Rate of Sri Lanka. The real interest rate is calculated by adjusting the inflation to the nominal interest rate of the country. When foreign investors look for investment opportunities in foreign countries, the interest rate is an important factor because the investors always expect to receive the interest rate prevailing in that country as the return for their investment. However, considering the time value of money, the real return they receive will be reduced due to inflation in the same country. As the results suggested, the Sri Lankan government and the Central Bank of Sri Lanka (CBSL) should ensure that an acceptable interest return is maintained, which is higher than the international interest rates, to attract more foreign portfolio investment. And at the same time, the government and CBSL should manage the country's money supply so that inflation will not compromise the real interest returns heavily.

The study has few limitations. Different models have used various factors as proxies such as accrual quality, persistence, predictability, smoothness, value relevance, timeliness, and conservatism (Jing, 2007; Dechow et al., 2010). However, we considered only the accruals quality to measure the earnings quality. Prior studies have used factors such as the growth rate of real GDP, Real interest rate, Real exchange rate, Gross capital flow, trade degree of openness, etc as determining factors to the FPI. However, the focus of this study limits only to the GDP growth and real interest rate.

Hence, we suggest considering other proxies of earnings quality such as Sloan ratio, persistence, predictability, and smoothness to determine the earnings quality, which might indicate a significant relationship between earnings quality and foreign portfolio investment. As macro-economic variables, inflation and exchange rate with foreign portfolio investment can be included. Moreover, the same study can be conducted to identify which factors are significant with respect to the twenty different sectors/GICS at Colombo Stock Exchange. Future studies can also consider sector-specific factors such as; S\&P SL 20, Dividend Yield, P/E Ratio, Price to Book Value, etc. 
Wijesinghe M.R.P., De Silva, A.L.C.M., KJM, 2021, 10 (Special Issue)

\section{References}

Abdelghany, K. E. (2005), Measuring the quality of earnings. Managerial Auditing Journal, 20(9), 1001-1015. https://doi.org/10.1108/02686900510625334

Agarwal, R. N., (1997), Foreign Portfolio Investment In Some Developing Countries: A Study of Determinants and Macroeconomic Impact. Indian Economic Review, 32(02), 217229. https://www.jstor.org/stable/29794138

Akimova, I., \& Schwodiauer, C. (2004), Ownership structure, corporate governance, and enterprise performance: empirical results for Ukraine. International Advances in Economic Research. 10, 28-42. https://doi:10.1007/BF02295575

Amarasekera, C. (2004), Managing and monitoring direct and portfolio investment flow: The case of Sri Lanka, Managing and Monitoring Direct and Portfolio Investment Flows: A Comparative Study of the SEACEN Countries, The SEACEN Centre.

Amr, N. E., Ahmed M.F., Maher A., Samir A., Nafee J., Abdalla, A., \& Sayed, H. (2019). Measuring Earnings Quality in Saudi Arabia Insurance Companies. International Journal of Applied Engineering Research 14, 4294-4309.

Ariyarathna K.G.U.S. \& Wijesinghe M.R.P. (2014, July 4-5). Impact of Foreign Investments on Market Performance, Proceedings of the Peradeniya University International Research Sessions (iPURSE), Sri Lanka. http://dlib.pdn.ac.lk/bitstream/1/4694/1/47.pdf

Aydin, N., Sayim, M., \& Yalama, A. (2007). Foreign ownership and firm performance: Evidence from Turkey. International Research Journal of Finance and Economics, 11, 103111.

Bailey, W., Kumar, A., \& Ng, D. (2008). Foreign investments of U.S. individual investors: Causes and consequences. Management Science, 54(3), 443-459. https://doi:10.1287/mnsc.1070.0793

Balamurali, N. \& Bogahawatte, C., (2004). Foreign Direct Investment and Economic Growth in Sri Lanka, Sri Lankan Journal of Agricultural Economics, Sri Lanka Agricultural Economics Association (SAEA), 6, 37-50. https://doi: 10.22004/ag.econ.205949

Barton, J., \& Simko, P. J. (2002). The balance sheet as an earnings management constraint. The Accounting Review, 77, 1-27. https://www.jstor.org/stable/3203322

Barbosa , N., \& Louri , H. (2003). Corporate performance: does ownership matter? A comparison of foreign - and domestic - owned firms in Greece and Portugal. 27. 73-102. https://doi.org/10.1007/s11151-005-4920-y

Bonizzi, B. (2013). Capital flows to emerging markets: An alternative theoretical framework. SOAS Department of Economics Working Paper Series, 186, The School of Oriental and African Studies, University of London.

Cahan, S. F., Emanuel, D., \& Sun, J. (2009). The effect of Earnings quality and country level Institutions on the value relevance of earnings, Review of Quantitative Finance Accounting, 33(4), 371-391. https://doi.org/10.1007/s11156-009-0117-z 
Wijesinghe M.R.P., De Silva, A.L.C.M., KJM, 2021, 10 (Special Issue)

Chan , K., Chan, L. K., Jegadeesh, N., \& Lakonishok, J. (2006). Earnings quality and stock returns, Journal of Business, 79(3), 1041-1182. https://doi.org/10.1086/500669

Collins, D. W., \& Hriber, P. (2002). Errors in estimating accruals: Implications for empirical research. Journal of Accounting Research, 40(1), 105-134. https://doi.org/10.1111/1475679X.00041

Coval, J. D., \& Moskowitz, T. J. (1999). Home bias at home: Local equity preference in domestic portfolios, The Journal of Finance, 6, 2045-2073.

DeAngelo, L. E. (1986). Accounting numbers as market valuation substitutes: A study of management buyouts of public stockholders, The Accounting Review, 61(3), 400-420.

Dechow, P. M., Sloan, R. G., \& Sweeney, A. P. (1995). Detecting earnings management. The Accounting Review, 70(2), 193-225.

Dechow, P., Ge, W., \& Schrand, C. (2010). Understanding earnings quality: A review of the proxies, their determinants and their consequences. Journal of Accounting and Economics, 50(2-3), 344-401. https://doi.org/10.1016/j.jacceco.2010.09.001

Demerjian, P. R., Lev, B., Lewis , M. F., \& McVay, S. E. (2013). Managerial ability and earnings quality. The Accounting Review, 88(2), 463-498. https://doi.org/10.2308/accr50318

Desai, H., Venkataraman, K., \& Krishnamurthy, S. (2006). Do short-sellers target firms with poor earnings quality? Review of Accounting Studies, 11, 71-90.

https://doi.org/10.1007/s11142-006-6396-X

Dimitropoulos, P. E., \& Asteriou, D. (2009). The value relevance of financial statements and their impact on stock prices: Evidence from Greece. Managerial Auditing Journal, 24(3), 248-265. https://doi.org/10.1108/02686900910941131

Ebaid, I. E. S. (2011). The value relevance of accounting-based performance measures in emerging economies: The case of Egypt. Management Research Review, 35(1), 69-88. https://doi.org/10.1108/01409171211190814

Ekeocha, P. C., (2008), Modelling The Long Run Determinants of Foreign Portfolio investment in An Emerging Market: Evidence From Nigeria. International Conference on Applied Economics.

Ekeocha, P. C., Ekeocha, C. . S., Malaolu, V. \& Oduh, M. O., (2012), Modelling the Long Run Determinants of Foreign Portfolio Investment in Nigeria. Journal of Economics and Sustainable Development, 3(8), 194-205.

Fama, E. (1970), Efficient Capital Markets: A Review of Theory and Empirical Work. The Journal of Finance, 25(2), 383-417. https://doi.org/10.2307/2325486

Falkenstein, E. G. (1996). Preferences for Stock Characteristics as Revealed by Mutual Fund Portfolio Holdings. The Journal of Finance, 51(1), 111-135.

https://doi.org/10.2307/2329304

Francis, J., LaFond, R., Olsson, P., \& Schipper , K. (2004). Costs of capital and earnings attributes. The Accounting Review, 79(4), 967-1010.

Gujarati, D. N. (2004). Basic Econometrics (4 edition.). Tata McGraw Hill. 
Gumus, G. K., Duru, A. \& Gungor, B., (2013), The Relationship Between Foreign Portfolio Investment And Macroeconomic Variables. European Scientific Journal, December, 9(34), 209-226. https://doi.org/10.19044/esj.2013.v9n34p\%25p

Hansen, B., Miletkov, M. K., \& Wintoki, M. B. (2015). Investor protection and the role of firm-level financial transparency. The Financial Review, 50(3), 393-434.

Healy, P. M. (1985). The effect of bonus schemes on accounting decisions. Journal of accounting and economics, 7(1-3), 85-107. https://doi.org/10.1016/0165-4101(85)90029-1

Helpman, E., Melitz, M. J., \& Yeaple, S. R. (2003). Exports versusu FDI with heterogeneous firms. American Economic Review, 94(1).300-316.

Hariprasad , B. (2016). FII ownership in Indian equity securities: The firm-level determinants. Theoretical Economics Letters, 6(5), http://dx.doi.org/10.4236/tel.2016.65095

https://www.ifrs.org/use-around-the-world/use-of-ifrs-standards-by-jurisdiction/

Jing, Z. (2007). Earnings quality, analysts, institutional investors and stock price synchronicity. PhD Thesis, Hong Kong Polytechnic University. https://theses.lib.polyu.edu.hk/bitstream/200/2576/1/b21898182.pdf

Jones, J. (1991). Earnings management during import relief investigations. Journal of Accounting Research, 29(2), 193-228. https://doi.org/10.2307/2491047

Khawar, M. (2003). Productivity and foreign direct investment - evidence from Mexico. Journal of Economic Studies, 30(1), 66-76. https://doi.org/10.1108/014435803104552778

Kumara, G.D.K. and Dayaratne, D.A.I., (2015). Long-Run Determinants of Equity Foreign Portfolio Investment (EFPI) in Sri Lanka: A Time Series Analysis with Autoregressive Distributive Lag (ARDL) Approach. Colombo Business Journal, 6(2), 1-21. http://doi.org/10.4038/cbj.v6i2.25

Lipe, R. (1990). The relation between stock returns and accounting earnings given alternative information. The Accounting Review, 65(1), 49-71.

Liyanage, E. (2016). Determinants of capital inflows: Evidence from Sri Lanka, Staff Studies, Central Bank of Sri Lanka, 44(1 \& 2).

Lyimo, G. D. (2014). Assessing the measures of quality of earnings: Evidence from India. European Journal of Accounting Auditing and Finance Research, 2(6), 17-28.

Melitz, M. J. (2002). The impact of trade on intra-industry reallocations and aggregate industry productivity. Econometrica, 71(6), 1695-1725.

Mollah, A. S., \& Talukdar, M. B. (2007). Ownership structure, corporate governance, and firm's performance in emerging markets: Evidence from Bangladesh. The International Journal of Finance, 19(1). Available at SSRN: https://ssrn.com/abstract=2385805

Mustafa A.M.M. and Santhirasegaram S. (2014), The Impact of Foreign Direct Investment on Economic Growth in Sri Lanka, Journal of Management, 8 (1), 27-32.

http://doi.org/10.4038/jm.v8i1.7551

Penman, S. H. (2003). The quality of financial statements: Perspectives from the recent stock. Accounting Horizons, 17, 77-96. 
Wijesinghe M.R.P., De Silva, A.L.C.M., KJM, 2021, 10 (Special Issue)

Rajeevan S. Ajward R. (2019), Board characteristics and earnings management in Sri Lanka, Journal of Asian Business and Economic Studies, 27(1), 2-18. https://doi.org/10.1108/JABES-03-2019-0027

Richardson, S. A., Sloan, R. G., Soliman, M. T., \& Tuna, I. (2001). Information in accruals about the quality of earnings. University of Michigan Business school. Retrieved from http://citeseerx.ist.psu.edu/viewdoc/download?doi=10.1.1.194.3047\&rep=rep1\&type=pdf

Shipper, K. \& Vincent, L., (2003). Earnings Quality. Accounting Horizons, 17, 97-110.

Srinidhi , B., Gul, F. A., \& Tsui, J. (2011). Female directors and earnings quality. Contemporary Accounting Research, 28(5), 1610-1644. https://doi.org/10.1111/j.19113846.2011.01071.x

Studenmund, A. H. (2014). Using Econometrics a Practical Guide (6 ${ }^{\text {th }}$ edition.), United Kingdom: Pearson Education Limited.

Teets, W. R. (2002). Quality of earnings: An introduction to the Issue in accounting education, Issue in Accounting Education, 17(4), 335-360.

Thilakaweera, (2012). Economic Impact of Foreign Direct Investment in Sri Lanka, Staff Studies, Central Bank of Sri Lanka, 41(1), 41-89. http://dx.doi.org/10.4038/ss.v41i1.4684

Todo, Y. (2011). Quantitative evaluation of the determinants of export and FDI: Firm-level evidence from Japan. The World Economy, 34(3), 355-381.https://doi.org/10.1111/j.14679701.2011.01331.x

Tucker, X. J. \& Zarowin , P. (2006). Does income smoothing improve earnings informativeness? The Accounting Review, 81(1), 251-270.

https://doi.org/10.2308/accr.2006.81.1.251

Waqas, Y., Hashmi, S. H. \& Nazir, M. I., (2015), Macroeconomic factors and foreign portfolio investment volatility: A case of South Asian countries, Future Business Journal, 1(1-2), 65-74. https://doi.org/10.1016/j.fbj.2015.11.002

Wijesinghe M.R.P and Kehelwalatenna S. (2017), The Impact of Earnings Quality on the Stock Returns of Listed Manufacturing Companies in the Colombo Stock Exchange, Colombo Business Journal.Vol.8(2), pp 68 - 89

Wijesinghe, M. R. P., \& Kavinda, D. D. C. (2017). The Impact of Leverage on Real Earnings Management: Evidences from Listed Manufacturing Companies in Colombo Stock Exchange. Kelaniya Journal of Management, 6(1), 63-82.

http://doi.org/10.4038/kjm.v6i1.7527

Yurt, C., \& Ergun, U. (2015). Accounting quality models: A comprehensive literature review, International Journal of Economics, Commerce and Management, 3(5), 33-66. 
Wijesinghe M.R.P., De Silva, A.L.C.M., KJM, 2021, 10 (Special Issue)

\section{Appendices}

\section{Appendix A}

Table 4: Sample Companies - Banks, Finance and Insurance Sector

\begin{tabular}{lrlr}
\hline \multicolumn{1}{c}{ Company Name } & Ticker & \multicolumn{1}{c}{ Company Name } & Ticker \\
\hline Aia Insurance Lanka Plc & CTCE & Lanka Ventures Plc & LVEN \\
Alliance Finance Company Plc & ALLI & Merchant Bank of Sri Lanka \& & MBSL \\
& & Finance Plc & MFL \\
Arpico Finance Company Plc & ARPI & Multi Finance Plc & NDB \\
Amana Takaful Plc & ATL & National Development Bank Pl & CSF \\
Asia Capital Plc & ACAP & Nation Lanka Finance Plc & NTB \\
Asia Asset Finance Plc & AAF & Nations Trust Bank Plc & PABC \\
Softlogic Life Insurance Plc & AAIC & Pan Asia Banking Corp Plc & PLC \\
Commercial Bank of Ceylon Plc & COMB & People'S Leasing \& Finance P & PMB \\
Commercial Credit \& Fin Plc & COCR & People'S Merchant Finance Pl & SAMP \\
Citizen Development Bank & CDB & Sampath Bank Plc & SDB \\
Central Finance Co Plc & CFIN & Sanasa Development Bank Plc & SEYB \\
Ceylinco Insurance Co Plc & CINS & Seylan Bank Plc & SFL \\
Dfcc Bank Plc & DFCC & Sinhaputhra Finance Plc & SFIN \\
Finance Co Plc/The & TFC & Singer Finance Lanka Plc & SEMB \\
First Capital Holdings Plc & CFVF & Smb Leasing Plc & SCAP \\
Hatton National Bank Plc & HNB & Softlogic Capital Plc & CRL \\
Hnb Assurance Plc & HASU & Softlogic Finance Plc & SFS \\
Housing Development Fin Corp & HDFC & Swarnamahal Financial Service & UAL \\
Janashakthi Insurance Co Plc & JINS & Union Assurance Plc & UBC \\
Lanka Orix Finance Plc & LOFC & Union Bank Of Colombo Plc & VFIN \\
Lanka Orix Leasing Co Plc & LOLC & Vallibel Finance Plc & \\
LB Finance Plc & LFIN & &
\end{tabular}

Note: Number of companies 43

Table 5: Sample Companies - Beverage Food and Tobacco Sector

\begin{tabular}{lrlr}
\hline Company Name & Ticker & Company Name & Ticker \\
\hline Bairaha Farms Plc & BFL & Lion Brewery Ceylon Plc & LION \\
Ceylon Beverage Holdings Plc & BREW & Lanka Milk Foods (CWE) Plc & LMF \\
Cargills (Ceylon) Plc & CARG & Nestle Lanka Plc & NEST \\
Ceylon Cold Stores Plc & CCS & Renuka Agri Foods Plc & RAL \\
Dilmah Ceylon Tea Co Plc & CTEA & Raigam Wayamba Salterns Plc & RWSL \\
Ceylon Tobacco Co Plc & CTC & Renuka Foods Plc & COCO \\
HVA Foods Plc & HVA & Three Acre Farms Plc & TAFL
\end{tabular}


Wijesinghe M.R.P., De Silva, A.L.C.M., KJM, 2021, 10 (Special Issue)

Keells Food Products Plc

KFP

Note: Number of companies 15

Table 6: Sample Companies - Chemicals and Pharmaceutical Sector

\begin{tabular}{lrlr}
\hline Company Name & \multicolumn{1}{c}{ Ticker } & Company Name & Ticker \\
\hline CIC Holdings Plc & CIC & Lankem Ceylon Plc & LCEY \\
Chemanex Plc & CHMX & Muller \& Phipps Ceylon Plc & MULL \\
Haycarb Plc & HAYC & Standard Capital Plc & SING \\
J.L. Morison Son \& Jones & MORI & & \\
\hline
\end{tabular}

Note: Number of companies 7

Table 7: Sample Companies - Construction and Engineering Sector and Footwear and Textiles Sector

\begin{tabular}{lrlr}
\hline Company Name & Ticker & Company Name ** & Ticker \\
\hline Access Engineering Plc & AEL & Ceylon Leather Products Plc & CLPL \\
Colombo Dockyards Plc & DOCK & Hayleys Fabric Plc & MGT \\
Lankem Developments Plc & LDEV & Odel Plc & ODEL \\
Mtd Walkers Plc & KAPI & & \\
\hline
\end{tabular}

Note: * Construction and Engineering Sector companies -4, ** Footwear and Textiles Sector companies -3 .

Table 8: Diversified Sector

\begin{tabular}{lrlr}
\hline Company Name & \multicolumn{1}{c}{ Ticker } & Company Name & Ticker \\
\hline Aitken Spence Plc & SPEN & John Keells Holdings Plc & JKH \\
Browns Investments Plc & BIL & Richard Pieris \& Co Plc & RICH \\
Ct Holdings Plc & CTHR & Softlogic Holdings Plc & SHL \\
Carson Cumberbatch Plc & CARS & Sunshine Holdings Plc & SUN \\
Dunamis Capital Plc & CSEC & Taprobane Holdings Plc & TAP \\
Expolanka Holdings Plc & EXPO & The Colombo Fort Land & CFLB \\
Browns Capital Plc & FLCH & Vallibel One Plc & VONE \\
Hayleys Plc & HAYL & & \\
\hline
\end{tabular}

Note: Number of companies 15

Table 9: Sample Companies - Healthcare Sector and IT Sector

\begin{tabular}{llll}
\hline Company Name* $^{*}$ & Ticker & Company Name** & Ticker \\
\hline Asiri Hospitals Holdings Plc & ASIR & E-Channelling Plc & ECL \\
Asiri Surgical Hospital Plc & AMSL & & \\
Ceylon Hospitals Plc & CHL & &
\end{tabular}


Wijesinghe M.R.P., De Silva, A.L.C.M., KJM, 2021, 10 (Special Issue)

Lanka Hospital Corp Plc LHCL

Nawaloka Hospitals Plc NHL

Note: *Healthcare Sector companies- 5, **IT Sector companies -1

Table 10: Sample Companies - Hotels and Travels Sector

\begin{tabular}{lrlr}
\hline Company Name & Ticker & Company Name & Ticker \\
\hline Aitken Spence Hotel Holdings & AHUN & Kandy Hotels Co 1938 Plc & KHC \\
Amaya Leisure Plc & CONN & Lighthouse Hotel Plc/The & LHL \\
Asian Hotels \& Properties Pl & AHPL & Marawila Resorts Plc & MARA \\
Browns Beach Hotels Plc & BBH & Nuwara Eliya Hotels Co Plc & NEH \\
Ceylon Hotels Corp Plc & CHOT & Palm Garden Hotels Plc & PALM \\
Citrus Leisure Plc & REEF & Pegasus Hotels Of Ceylon Plc & PEG \\
Dolphin Hotels Plc & STAF & Renuka City Hotels Plc & RENU \\
Eden Hotel Lanka Plc & EDEN & Serendib Hotels Plc & SHOT \\
Fortress Resorts Plc & RHTL & Sigiriya Village Hotels Plc & SIGV \\
Galadari Hotels Lanka Plc & GHLL & Tal Lanka Hotels Plc & TAJ \\
Hotel Sigiriya Plc & HSIG & The Kingsbury Plc & SERV \\
\hline
\end{tabular}

Note: Number of companies 22

Table 11: Sample Companies - Investment Trust Sector and Land and Property Sector.

\begin{tabular}{lrlr}
\hline Company Name* $^{*}$ & Ticker & Company Name** & Ticker \\
\hline C T Land Development Plc & CTLD & Ascot Holdings Plc & ASCO \\
Cargo Boat Development Co & CABO & Ceylon Guardian Investment & GUAR \\
City Housing \& Real Estate C & CHOU & Ceylon Investment Plc & CINV \\
Colombo Land \& Dvlp Co Plc & CLND & Colombo Fort Investments Plc & CFI \\
Commercial Development Co & COMD & Colombo Investment Trust Plc & CIT \\
East West Properties Plc & EAST & Guardian Capital Partners Pl & WAPO \\
Kelsey Development Plc & KDL & Lanka Century Investments Pl & GREG \\
Overseas Realty Ceylon Plc & OSEA & Lee Hedges Plc & SHAW \\
Seylan Developments Plc & CSD & Renuka Holdings Plc & RHL \\
Serendib Engineering Group P & IDL & & \\
York Arcade Holdings Plc & YORK & & \\
\hline
\end{tabular}

Note: *Land and Property Sector companies - 11, Investment Trust Sector companies - 9 
Wijesinghe M.R.P., De Silva, A.L.C.M., KJM, 2021, 10 (Special Issue)

Table 12: Motors Sector and Oil Palm Sector.

\begin{tabular}{lclr}
\hline Company Name* & Ticker & Company Name** $^{*}$ & Ticker \\
\hline C M Holdings PLC & COLO & Bukit Darah Plc & BUKI \\
Diesel \& Motor Engineering & DIMO & Good Hope Plc/The & GOOD \\
Lanka Ashok Leyland Plc & ASHO & Indo-Malay Plc/The & INDO \\
Sathosa Motors Plc & SMOT & Selinsing Plc & SELI \\
United Motors Lanka Plc & UML & Shalimar Malay Plc & SHAL \\
\hline
\end{tabular}

Note: * Motors Sector companies - 5, **Oil Palm Sector companies - 5

Table 13: Sample Companies - Manufacturing Sector.

\begin{tabular}{lrlr}
\hline Company Name & Ticker & Company Name & Ticker \\
\hline Abans Electricals Plc & ABAN & Kelani Tyres Plc & TYRE \\
Acl Cables Plc & ACL & Lanka Aluminium Indus Plc & LALU \\
Acl Plastics Plc & APLA & Lanka Tiles Plc & TILE \\
Acme Printing \& Packaging Pl & ACME & Lanka Walltile Plc & LWL \\
Agstar Plc & AGST & Laxapana Batteries Plc & LITE \\
Alufab Plc & ALUF & Printcare Plc & CARE \\
Blue Diamonds Jewellery Worl & BLUE & Regnis Lanka Plc & REG \\
Bogala Graphite Lanka Plc & BOGA & Richard Pieris Exports Plc & REXP \\
Ceylon Grain Elevators Plc & GRAN & Royal Ceramics Lanka Plc & RCL \\
Chevron Lubricants Lanka Plc & LLUB & Sierra Cables Plc & SIRA \\
Central Industries Plc & CIND & Singer Industries Ceylon Plc & SINI \\
Dankotuwa Porcelain Plc & DPL & Swisstek Ceylon Plc & PARQ \\
Dipped Products Plc & DIPD & Teejay Lanka Plc & TJL \\
Hayleys Fibre Plc & HEXP & Tokyo Cement Co Lanka Plc & TKYO \\
Kelani Cables Plc & KCAB & & \\
\hline
\end{tabular}

Note: Number of companies 29

Table 14: Sample Companies - Plantations, Power and Energy and Service Sector.

\begin{tabular}{lclr}
\hline Company Name & Ticker & Company Name & Ticker \\
\hline Plantations Sector & & Power and Energy Sector & \\
Agalawatte Plantations Plc & AGAL & Lotus Hydro Power Plc & HPFL \\
Balangoda Plantations Plc & BALA & Lanka Ioc Plc & LIOC \\
Bogawantalawa Tea Estates & BOPL & Laugfs Gas Plc - Voting & LGL \\
Elpitiya Plantations Plc & ELPL & Panasian Power Plc & PAP \\
Hapugastenne Plantations Plc & HAPU & Resus Energy Plc & HPWR \\
Horana Plantations Plc & HOPL & Vallibel Power Erathna Plc & VPEL
\end{tabular}


Wijesinghe M.R.P., De Silva, A.L.C.M., KJM, 2021, 10 (Special Issue)

Kahawatte Plantations Plc

KAHA Vidullanka Plc

VLL

Kegalle Plantation Plc

KGAL

Kelani Valley Plantations Pl

KVAL Services Sector

Kotagala Plantations Plc

Malwatte Valley Plant-Voting

KOTA Ceylon Tea Brokers Plc

CTBL

MAL John Keels Plc

JKL

Madulsima Plantations Plc

MADU

Maskeliya Plantation Plc

MASK

Namunukula Plantations Plc

NAMU

Talawakelle Tea Estates Plc

TPL

Watawala Plantation Plc

WATA

Note: Plantation Sector companies - 16, Power and Energy Sector companies - 7, Service Sector companies -2 .

Table 15: Sample Companies - Trading, Stores and Supplies and Telecommunications Sector.

\begin{tabular}{lrlr}
\hline Company Name & Ticker & Company Name & Ticker \\
\hline Trading & & Stores and Supplies & \\
Brown \& Co Plc & BRWN & Colombo City Holdings Plc & PHAR \\
Ceylon \& Foreign Trades Plc & CFT & Gestetner of Ceylon Plc & GEST \\
Cw Mackie Plc & CWM & Hunter \& Co Plc & HUNT \\
Office Equipment Plc & OFEQ & & \\
Radiant Gems International Plc & RGEM & Telecommunication & \\
Singer Sri Lanka Plc & SINS & Dialog Axiata Plc & DIAL \\
Tess Agro Plc & TESS & Sri Lanka Telecom Plc & SLTL \\
\hline
\end{tabular}

Note: Trading Sector companies - 7, Stores and Supplies Sector companies - 3,

Telecommunications Sector companies -2 . 


\section{Appendix B}

Table 16: Summary of Descriptive Statistics

\begin{tabular}{|c|c|c|c|c|c|c|c|c|c|c|c|c|}
\hline Statistic & TNFP* & TFS* & TFP* & TA* & SI & ROE & ROA & OPM & MC* & BETA & GDP & IR \\
\hline Mean & $(145.00)$ & 261.00 & 116.00 & 145.00 & 6353.794 & 0.03 & 0.01 & 0.15 & $12,800.00$ & 1.2622 & 0.06 & 0.09 \\
\hline Median & 0.02 & 2.70 & 314 & $(0.56)$ & 27 & 0.02 & 0.01 & 0.12 & .00 & 49766 & 0.05 & 0.08 \\
\hline Maximum & $17,600.00$ & $611,000.00$ & $1,990.00$ & $1,000.00$ & 7298.95 & 1.15 & 0.47 & 1.17 & $252,000.00$ & 32.78721 & 0.16 & 0.13 \\
\hline Minimum & $(606,000.00)$ & 0.00 & 0.00 & $(19,800.00)$ & 4965.77 & -1.24 & -0.22 & -0.99 & 67.20 & -8.15436 & 0.00 & 0.05 \\
\hline Std. Dev. & $9,870.00$ & $9,950.00$ & 702.00 & $4,590.00$ & 621.3117 & 0.08 & 0.03 & 0.23 & $26,900.00$ & 1.121718 & 0.03 & 0.02 \\
\hline
\end{tabular}

Note: Number of Observations 3783 (* variables are in millions)

\section{Appendix C}

Table 17: Summary of Panel Unit Root Test Results

\begin{tabular}{|c|c|c|c|c|c|c|c|c|c|c|c|c|}
\hline Method & $\begin{array}{c}\text { LTNFP } \\
\text { Prob. }\end{array}$ & $\begin{array}{l}\text { LTFS } \\
\text { Prob. }\end{array}$ & $\begin{array}{l}\text { LTFP } \\
\text { Prob. }\end{array}$ & $\begin{array}{l}\text { LROE } \\
\text { Prob. }\end{array}$ & $\begin{array}{l}\text { LROA } \\
\text { Prob. }\end{array}$ & $\begin{array}{l}\text { LOPM } \\
\text { Prob. }\end{array}$ & $\begin{array}{c}\text { LBETA } \\
\text { Prob. }\end{array}$ & $\begin{array}{r}\text { LSI } \\
\text { Prob. }\end{array}$ & $\begin{array}{l}\text { LMC } \\
\text { Prob. }\end{array}$ & $\begin{array}{l}\text { LGDP } \\
\text { Prob. }\end{array}$ & $\begin{array}{l}\text { DLIR } \\
\text { Prob. }\end{array}$ & $\begin{array}{l}\text { LTA } \\
\text { Prob. }\end{array}$ \\
\hline $\begin{array}{l}\text { Levin, Lin \& } \\
\text { Chu t }\end{array}$ & 0.0000 & 0.0000 & 0.0000 & 0.0000 & 0.0000 & 0.2902 & 0.0000 & 0.0003 & 0.0000 & 0.0000 & 1.0000 & 0.0000 \\
\hline$\underset{\text { Shin W-stat }}{\text { Im, Pesaran and }}$ & 0.0000 & 0.0000 & 0.0000 & 0.0000 & 0.0000 & 0.0000 & 0.0000 & 0.0000 & 0.0000 & 0.0000 & 0.0000 & 0.0126 \\
\hline$\underset{\text { Chi-square }}{\text { AD* }}=\underset{*}{\text { Fisher }}$ & 0.0000 & 0.0000 & 0.0000 & 0.0000 & 0.0000 & 0.0000 & 0.0000 & 0.0000 & 0.0000 & 0.0000 & 0.0000 & 0.0006 \\
\hline $\begin{array}{l}\text { PP - Fisher Chi- } \\
\text { square }_{* *}\end{array}$ & 0.0000 & 0.0000 & 0.0000 & 0.0000 & 0.0000 & 0.0000 & 0.0000 & 0.0000 & 0.0000 & 0.0000 & 0.0000 & 0.0000 \\
\hline
\end{tabular}

Note: **Probability for Fisher tests are computed using asymptotic chi-square distribution. All other tests assume asymptotic normality.

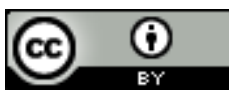




\section{Appendix D}

Table 18: Correlation Matrix

\begin{tabular}{|c|c|c|c|c|c|c|c|c|c|}
\hline Variable & LROE** & LROA & LOPM & LMC & LBETA & LTA & LSI & LGDP & DLIR \\
\hline LROE & 1.000000 & 0.783183 & 0.204112 & 0.118464 & 0.019079 & 0.233337 & 0.043034 & 0.066340 & 0.009504 \\
\hline LROA** & $0.783183^{*}$ & 1.000000 & 0.315872 & 0.027518 & 0.029871 & 0.066427 & 0.055937 & 0.065640 & 0.005489 \\
\hline LOPM & 0.204112 & 0.315872 & 1.000000 & 0.076049 & 0.000542 & 0.007324 & 0.016549 & 0.063364 & 0.009915 \\
\hline LMC & 0.118464 & 0.027518 & 0.076049 & 1.000000 & 0.161016 & 0.582978 & 0.089479 & 0.024650 & 0.001533 \\
\hline LBETA & 0.019079 & 0.029871 & 0.000542 & 0.161016 & 1.000000 & 0.047213 & 0.104515 & 0.067273 & 0.011614 \\
\hline LTA & 0.233337 & 0.066427 & 0.007324 & 0.582978 & 0.047213 & 1.000000 & 0.048813 & 0.008972 & 0.018192 \\
\hline LSI & 0.043034 & 0.055937 & 0.016549 & 0.089479 & 0.104515 & 0.048813 & 1.000000 & 0.027909 & 0.131836 \\
\hline LGDP & 0.066340 & 0.065640 & 0.063364 & 0.024650 & 0.067273 & 0.008972 & 0.027909 & 1.000000 & 0.334552 \\
\hline DLIR & 0.009504 & 0.005489 & 0.009915 & 0.001533 & 0.011614 & 0.018192 & 0.131836 & 0.334552 & 1.000000 \\
\hline
\end{tabular}

Note: ** Represent the highly correlated explanatory variables. * Represent the correlation 
Wijesinghe M.R.P., De Silva, A.L.C.M., KJM, 2021, 10 (Special Issue)

\section{Appendix E}

Table 19: Random Effect Output - Relationship between LTNFP and LROE, LOPM, LMC, LBETA, LMI, LTA, LGDP and LIR.

\begin{tabular}{lrrr}
\hline \multicolumn{1}{c}{ Variable } & Coefficient & t- statistic & \multicolumn{1}{c}{ Prob. } \\
\hline LROE & 0.2151 & 2.6408 & $0.0084^{* *}$ \\
LOPM & -0.1548 & -1.6859 & 0.0922 \\
LMC & 1.0624 & 12.1208 & $0.0000^{* *}$ \\
LTA & 0.0245 & 0.5062 & 0.6128 \\
LMI & 2.0529 & 2.8050 & $0.0051^{* *}$ \\
LGDP & 0.1915 & 1.8452 & 0.0653 \\
LBETA & -0.2143 & -2.5879 & $0.0098^{* *}$ \\
DLIR & -0.8686 & -2.4037 & $0.0164^{*}$ \\
C & -26.3191 & -4.0970 & 0.0000 \\
R-squared & 0.2320 & Prob.(F-statistic) & $0.0000^{* *}$ \\
Adjusted R-squared & 0.2250 & & \\
\hline
\end{tabular}

Note: Number of observations 887 (* represent probabilities are significant at 5\% level, ** represents probabilities are significant at $1 \%$ level)

Table 20: Fixed Effect Output - Relationship between LTFP and LROE, LOPM, LMC, LBETA, LMI, LTA, LGDP and LIR.

\begin{tabular}{lrrr}
\hline \multicolumn{1}{c}{ Variable } & Coefficient & t- statistic & \multicolumn{1}{c}{ Prob. } \\
\hline LROE & 0.1596 & 2.0292 & $0.0426^{*}$ \\
LOPM & 0.0794 & 0.7979 & 0.4251 \\
LMC & 1.7168 & 8.7070 & $0.0000^{* *}$ \\
LTA & -0.0438 & -1.0227 & 0.3067 \\
LMI & 1.9108 & 3.1028 & $0.0020^{* *}$ \\
LGDP & 0.1914 & 2.4070 & $0.0162^{*}$ \\
LBETA & -0.0973 & -1.3713 & 0.1705 \\
DLIR & -0.7680 & -2.9487 & $0.0032 * *$ \\
C & -37.8067 & -7.2152 & 0.0000 \\
R-squared & 0.6390 & Prob.(F-statistic) & $0.0000^{* *}$ \\
Adjusted R-squared & 0.5788 & & \\
\hline
\end{tabular}

Note: Number of observations 1483 (* represent probabilities are significant at 5\% level, ** represents probabilities are significant at $1 \%$ level) 
Wijesinghe M.R.P., De Silva, A.L.C.M., KJM, 2021, 10 (Special Issue)

Table 21: Fixed Effect Output - Relationship between LTFS and LTOE, LOPM, LMC, LBETA, LMI, LTA, LGDP and LIR.

\begin{tabular}{|c|c|c|c|}
\hline Variable & Coefficient & t- statistic & Prob. \\
\hline LROE & 0.0969 & 1.2368 & 0.2164 \\
\hline LOPM & 0.0524 & 0.5071 & 0.6122 \\
\hline LMC & 1.8528 & 9.0714 & $0.0000^{* *}$ \\
\hline LTA & -0.0320 & -0.7479 & 0.4547 \\
\hline LMI & 3.2050 & 5.1094 & $0.0000 * *$ \\
\hline LGDP & 0.1724 & 2.1131 & $0.0348 *$ \\
\hline DLIR & -0.4293 & -1.5739 & 0.1158 \\
\hline LBETA & 0.2066 & 2.6141 & $0.0091 * *$ \\
\hline $\mathbf{C}$ & -52.8709 & -9.9533 & 0.0000 \\
\hline R-squared & 0.6368 & $\operatorname{Prob}(F-$-statistic $)$ & $0.0000^{* *}$ \\
\hline Adjusted R-squared & 0.5738 & & \\
\hline
\end{tabular}

Kelaniya Journal of Management | 2021 | Vol. 10 | Special Issue | Page 24 